\title{
Enabling Post-GFC Mineral Tax Policy Reform through Strategic Stakeholder Communication
}

\author{
Tapan K. Sarker, Griffith Business School, Griffith University, Australia
}

\begin{abstract}
This paper analyses the role of stakeholders in tax policy reform with reference to the Australian experience in attempting to introduce a resource rent tax by replacing the existing royalty based system. By discussing why some groups of stakeholders are more powerful than others and why democratic governments are required to develop policy in consultation with their stakeholders, this paper proposes some ways by which governments can effectively manage stakeholders, particularly by building a winning coalition through strategic stakeholder communication.
\end{abstract}

Index terms-Australia, global financial crisis, mineral tax policy reform, stakeholders

\section{INTRODUCTION}

The Global Financial Crisis (GFC) caused many governments to look for new methods of raising revenue. In particular, economies, such as Australia, that have increased their budget deficits through fiscal stimulus packages designed to ameliorate the effects of the global financial crisis are looking for options to reduce their budget deficits and strengthen the economy. In this regard, economic instability in the European Union, where Greece faced the risk of default on its national debt, reveals the risk posed by excessive budget deficits. Pressure for fiscal consolidation will compel many countries to seek new revenues in coming years, and the impact of this process on growth will depend largely on their success in identifying the revenue sources that are least distorting and least damaging to growth [1].

For a resource rich country like Australia, the introduction of a resource rent tax (the Resource Super Profits Tax) to replace the current ad valorem or royalty based system seemed a perfect policy solution that could increase the efficiency of the resource taxation system [2]. A resource rent tax would also allow for the redistribution of the wealth gained from mining to less resource-rich areas [3]. However, political upheaval occurred due to the Australian Government announcing the tax as a complete package, rather than first engaging and negotiating with stakeholders and building a winning coalition to drive the reform through. This triggered a media campaign against the tax launched by mining companies, which caused political chaos including the removal of a democratically elected Prime Minister [4]. After the removal of the

Manuscript received August1, 2010; revised September 21, 2011

Submitted to International Journal of Trade, Economics, and Finance (IJTEF, ISSN:2010-023X). This paper was presented as a keynote speech at the 2011 International Conference on Financial Management and Economics - ICFME 2011 held in Hong Kong, July 2-3, 2011 incumbent Prime Minister, a significant compromise was negotiated between the new Prime Minister and the largest companies in the mining industry in the form of the Mineral Resource Rent Tax. The difficulties experienced by the Australian Government in implementing significant taxation policy reform highlight the role that stakeholders play in policy formulation in democracies [4].

\section{The Role OF STAKeHOLDERS IN TAX POLICY REFORM}

Who are stakeholders and why are they important? Stakeholders may be thought of as those interest groups, who engage in, and influence, the political process in order to protect their economic interests, to avoid negative externalities or to maintain political power [5]. A policy formulated through a process of consultation will be seen as more legitimate, because it meets the preference of a majority of interest groups who are affected by the decision, and adds transparency and accountability to the policy making process. Governments may also need to engage with stakeholders because they have practical knowledge, experience and expertise [6]. Further, to avoid tax culture shock, democratic governments are required to engage in deliberative democracy and negotiate with their key stakeholders in order to achieve tax policy reform that is politically acceptable [7].

However, tax reform is always a politically difficult process, and trade-offs between different groups of stakeholders is often required. The need to make trade-offs is one of the most difficult parts of tax reform, since it is common for democratic policy makers to opt for tax policy changes that serve the interests of particular constituencies. A further concern in the present environment is that the growth of budget deficits in many countries will make it difficult to pursue pro-growth tax reforms that result in significant revenue losses in the short term [8]. In this scenario, the long-term policy objectives of government often conflict with the short-term interests of stakeholders. Governments want to maximise taxation revenue without distorting the market (and causing a deadweight loss). On the other hand, the affected companies want to minimize to the greatest extent possible their taxation liability. This means that they are likely to resist an actual or perceived increase in their taxation liability. Accordingly, the longterm policy objectives of government often conflict with the short-term interests of stakeholders. This makes policy formulation in democracies difficult, as, to be legitimate, policy must be the result of a negotiated agreement [9].

For example, key stakeholders in the Australian Government's mining tax may include the Commonwealth Department of Treasury, the State Governments of 
Queensland and Western Australia (who currently collect royalties), large mining companies, emerging mining companies, superannuation funds, mine workers, unions, people living in mining towns, people living in non-mining states of Australia, international resource buyers, future generations, academics and the media.

With such a multitude of stakeholders, how do governments identify which stakeholders are the most important? Mitchell, Agle and Wood [10] proposed that three factors be considered: (1) the stakeholders' power to influence decision making; (2) the legitimacy of their relationship to the government; and (3) the urgency of their claim. Accordingly, stakeholders with the greatest interest in government policies should have the greatest say in their outcomes [11]. This would make mining companies the most important stakeholders in a resource rich country like Australia, as they are the ones most directly affected by the proposed mining tax. Australia has some of the world's richest natural resource deposits, and export earnings for commodity exports are predicted to reach AUD 169.8 billion in 2010-11, an increase of $28.4 \%$. Mining exports account for $37.6 \%$ Australia's total exports [12]. Australia's reliance on exports gives power to the mining companies as stakeholders.

\section{STAKEHOLDERS AND THE DYNAMICS OF REFORM}

According to Duggin [13], stakeholder engagement should be integrated into the policy development process, which has five key phases: 1 . Recognising and defining the problem or issue; 2. Identifying possible solutions by gathering and analysing information and consulting with stakeholders; 3. Choosing the best solution; 4. Implementing the policy; and 5. Evaluating the policy. In all five phases, early engagement with stakeholders is vital. Strategic choices should be made about the timing and nature of the approach to stakeholders [14].

Although stakeholders should be involved at all stages of the policy development cycle, their interests and objectives may change over the course of the reform, and accordingly five different management strategies should be adopted to account for this.

These five strategies are:

- Stage 1: Idea formulation and organisation of reform. This involves providing reports, indicators, donor advice, and study tours to change how stakeholders view the benefits and costs of current practices and to illustrate the need for reform.

- Stage 2: Solution design. Stakeholders should be gradually brought into the process through a controlled strategy of information disclosure, participation and consultation.

- Stage 3: Broadening and marketing reform ideas. Here, the focus should be on communicating the right message to the right stakeholders through the right medium.

- Stage 4: Political acceptance and adoption. This requires credible political backing to gain parliamentary approval for the reform.

- Stage 5: Implementation. At this stage, stakeholders may try to delay, undermine, or reverse the benefits. In this situation, policymakers should communicate strategically to help build pro-reform alliances and coalitions among groups of stakeholders [15].

In each of the above five phases, early and strategic engagement with stakeholders is vital [16]. Rather than engage in broad consultation as a first step, strategic choices were made about the timing and nature of the approach to stakeholders. This can be done through strategic communication to help build pro-reform alliances and coalitions among groups of stakeholders [17].

\section{BuILding A WinNing CoALITION Through StrategiC COMMUNICATION}

The key avenue for stakeholder management is strategic communication, because it helps identify those stakeholders who will help or hinder reform and then leverages that knowledge to influence their behaviour. By doing so, it provides a framework for engaging stakeholders to address risks and barriers to reform and helps to mitigate risks of reform, accelerate reform adoption, and achieve sustainable reform [18].

Strategic communication is a planned, analytical approach for determining whom a given project must engage to achieve its reform objectives, for what purpose, and when and how this engagement takes place. It helps identify those stakeholders who will help or hinder reform and then leverages that knowledge to influence their behaviour. By doing so, strategic communication provides a framework for engaging stakeholders to address risks and barriers to reform and helps to:

1) Mitigate risks. Reform can be easily derailed from staunch opposition or a simple lack of support or interest. Strategic communications identifies risk areas early and develops approaches to mitigate or minimise those risks;

2) Accelerate reform adoption. Successful reform requires support from a broad range of stakeholders. By engaging those stakeholders, strategic communications can increase understanding, achieve behaviour change, generate support, and accelerate the pace of reform; and

3) Achieve sustainable reform. Changing legislation or policy advances reform, but unless the new processes or reformed policies are accepted by the public and "owned" by stakeholders, the reform may be ineffective or short-lived [19].

The World Bank found that opposition to most policy reform proposals is linked to scepticism of the effectiveness of reform; legitimate concerns about the principles and design of reform; ideological principles; personal interest in the existing system. It also found that support of the reforms is caused by political advantages and commitments; technocratic agendas and professional values; personal interest in economic gains from reform; support for broader policy goals linked to the results of business registration reform; donor and other exogenous pressures (such as a history of partnership between the private and public sector) [20]. This means that stakeholders who shifted towards reform had their support stimulated by better information; 
new opportunities for rent seeking; better organisation and advocacy capacities; a change in the reform design, or strategic retreat and diversion of resistance into the implementation phase [21]. As such, strategic communication should be directed at communicating information directed at these motivations in order to increase stakeholder support for, and decrease opposition to, the proposed reform, as illustrated by Table 1 .

TABLEI: STRATEGIC COMMUNICATION OF INCENTIVES

\begin{tabular}{|c|c|}
\hline Objectives & $\begin{array}{l}\text { Stakeholder management } \\
\text { strategy }\end{array}$ \\
\hline \multicolumn{2}{|l|}{$\begin{array}{l}\text { Weaken Incentives to } \\
\text { Oppose Reform }\end{array}$} \\
\hline $\begin{array}{l}\text { Skepticism of the } \\
\text { effectiveness of reform }\end{array}$ & $\begin{array}{l}\text { Provide concrete information or } \\
\text { results in other countries }\end{array}$ \\
\hline $\begin{array}{l}\text { Legitimate } \\
\text { about design of the } \\
\text { reform }\end{array}$ & $\begin{array}{l}\text { Discuss concerns, accommodate } \\
\text { as needed without substantial } \\
\text { damage to results of reform }\end{array}$ \\
\hline $\begin{array}{l}\text { Ideological principles } \\
\text { (hardcore opposition) }\end{array}$ & $\begin{array}{l}\text { Reduce participation in the } \\
\text { reform process, link reforms to } \\
\text { high priority political goals such } \\
\text { as unemployment }\end{array}$ \\
\hline $\begin{array}{l}\text { Personal interest in the } \\
\text { existing system } \\
\text { (hardcore opposition) }\end{array}$ & $\begin{array}{l}\text { Expose realities of current } \\
\text { system, deploy concrete evidence } \\
\text { of the benefits and costs of the } \\
\text { new system }\end{array}$ \\
\hline \multicolumn{2}{|l|}{$\begin{array}{l}\text { Strengthen Incentives to } \\
\text { Support Reform }\end{array}$} \\
\hline $\begin{array}{l}\text { Political commitments to } \\
\text { mark a new political } \\
\text { regime }\end{array}$ & $\begin{array}{l}\text { Link reform to high priority } \\
\text { political goals, assemble } \\
\text { coalition of allies with political } \\
\text { influence }\end{array}$ \\
\hline $\begin{array}{l}\text { Technocratic agendas } \\
\text { and professional values }\end{array}$ & $\begin{array}{l}\text { Provide information on the } \\
\text { benefits and costs of the new } \\
\text { system, clear vision design of the } \\
\text { new system }\end{array}$ \\
\hline $\begin{array}{l}\text { Personal interest in } \\
\text { economic gain from } \\
\text { reform }\end{array}$ & $\begin{array}{l}\text { Demonstrate the financial gains } \\
\text { from the new system }\end{array}$ \\
\hline $\begin{array}{l}\text { Support for broader } \\
\text { policy goals linked to the } \\
\text { results of reform }\end{array}$ & $\begin{array}{l}\text { Link reform to high priority } \\
\text { political goals, use international } \\
\text { information to document effects }\end{array}$ \\
\hline $\begin{array}{l}\text { Donor and exogenous } \\
\text { pressures }\end{array}$ & $\begin{array}{l}\text { Link reform to exogenous } \\
\text { pressures as "drivers" of reform }\end{array}$ \\
\hline
\end{tabular}

Because support for reform is linked to incentives, strategic communication can be directed at communicating information directed at these motivations in order to increase stakeholder support for, and decrease opposition to, the proposed reform. This can be summarised into the three main objectives of strategic communication:

1) Changing perceptions of the benefits and costs of reform in order to alter incentives;

2) Creating new means for stakeholders to participate in the reform process; and

3) Building organisation and capacities of pro-reform units and interest groups [23].

The importance of meaningful mandates in democratic governments makes strategic communication all the more important. Successful reforms have usually been accompanied by consistent and coordinated efforts to persuade voters and stakeholders of the need for reform and the costs of non-reform [24].

Given the above, there are seven steps policymakers can take to use strategic communication to build a winning coalition and drive through reform:

1) Manage stakeholders by selectively and progressively building pro-reform coalitions. Consensus is not the right principle for stakeholder management;

2) Structure direct participation of key stakeholders to produce concrete, practical opportunities for dialogue;

3) Generate and communicate factual and credible information about the costs of the status quo and the benefits of reform;

4) Create new institutions with incentives to perform for clients, rather than re-engineering existing institutions;

5) Help supportive stakeholders become more effective in advocating change;

6) Move as quickly as possible, balancing the costs and benefits of expanding stakeholder participation in each phase; and

7) Assemble $a$ winning coalition by changing the reform scope, speed, content and compensation as needed [25].

\section{Mineral Resource Tax Reform In Australia}

Currently, mining taxation in Australia involves a system of state-based royalties, which are generally accepted to be economically inefficient and distortionary [26].

For a developed and resource rich country like Australia, the introduction of a resource rent tax to replace the current ad valorem or royalty based system has long been considered by economists to be a "potentially robust source of relatively non-distorting revenue" [27]. The introduction of such a tax was also intended to allow for the redistribution of the wealth gained from mining to less resource-rich States [28].

It was against this background that the Henry Tax Review proposed the taxation of mineral rents on 2 May 2010. The original proposal involved a Resources Super Profits Tax (RSPT): a $40 \%$ tax on all profits made by mining companies above the $6 \%$ rate of return. This was modelled to eliminate Australia's budget deficit within a few years. Further, a profits tax is generally accepted as being more economically efficient than the existing system of royalty charges, as, unlike royalty charges, profit taxes do not make marginal projects any less viable [29].

The importance of mining to Australia's economy, which motivated the Australian Government to propose the resource rent tax in the form of the RSPT in the first place, is also the reason why this proposal triggered such voter discontent. Revenues from mining form a significant part of Australia's GDP, and account for well over one third (37.6\%) of Australia's total exports [30]. Accordingly, any reduction in the revenues of mining companies was considered to be jeopardising the Australian economy itself. This was reflected by the fact that mining shares on the Australian Stock Exchange (ASX) fell immediately when the RSPT was proposed: between 3 to 7 percent [31].

The proposed introduction of the resource rent tax also attracted significant criticism from mining companies because of the Australian Government's perceived unwillingness to negotiate key details of the tax with them. ${ }^{1}$

\footnotetext{
${ }^{1}$ Queensland Resources Council, Personal Communication, Seminar on the Resources Super Profits Tax, June 15, 2010; Minerals Council of Australia "Minerals, Resources and the prosperity of all Australians", (2010) Policy Brief, available at www.minerals.org.au/_data/assets/pdf_file/MCA_News/MCA_Future_Ta x_System.pdf [Accessed August 1, 2010]; Minerals Council of Australia
} 
Many mining companies believed that the Australian Government should have first engaged and negotiated with stakeholders to help build a winning coalition to develop the reforms, rather than announcing the resource rent tax as a finalised package [32]-[33]. A media campaign opposing the tax was subsequently launched by the mining companies. This political unrest triggered a highly unorthodox - and successful - leadership challenge in the first term of a democratically elected Prime Minister, made especially remarkable by the fact that incumbent Prime Minister had been elected to power in a landslide victory not three years earlier.

After the removal of the incumbent Prime Minister, a significant compromise was negotiated between the new Australian Prime Minister and the three biggest mining companies: BHP Billiton, Rio Tinto and Xstrata, in the form of the Mineral Resource Rent Tax (MRRT). The new MRRT involves a $30 \%$ tax on all profits above the $12 \%$ rate of return, which is significantly more generous to mining companies than the arrangement originally proposed by the RSPT. The difficulties experienced by the Australian Government in implementing significant taxation policy reform highlight the role that stakeholders play in policy formulation and negotiation in democratic countries [34].

The Australian experience demonstrates what occurs when governments fail to effectively negotiate with their stakeholders: a "tax culture shock". A tax culture shock is political and social upheaval when the tax culture changes against the will of voters or against a vested interest group. These upheavals are largest and unavoidable when a sudden or abrupt transformation of a country's tax culture is attempted [35].

By contrast, smoother, gradualist approaches to transformation of the taxation system may avoid serious shocks to the tax culture of a country. This usually takes the form of negotiation and consultation with affected stakeholders through deliberative democracy. Not only does the extensive consultation process required ensure that policy decisions are well-justified, but also that decisions gain legitimacy from the consultation process. This is because a decision gains legitimacy, not because it simply meets the preferences of a majority of citizens, but because it has weathered the test of public justification [36].

In Australia, the "tax culture shock" was seen in the opposition encountered by the proposed taxation of mineral rents by key stakeholders, such as mining companies. This involved a $\$ 27$ million advertising campaign by the mining industry which shifted public opinion against the mining tax. In the same year that the mining tax as originally proposed by the Henry Tax Review was scrapped, Xstrata announced a $430 \%$ surge in earnings, and Rio Tinto announced an $161 \%$ increase in its earnings. BHP is also expected to deliver one of the biggest half-year earnings results in Australian and British industry. These figures are merely indicative of the benefits large mining companies gain from their mining operations in Australia [37], and also illustrate that they are powerful stakeholders who cannot be ignored in any

“Minerals Resource Rent Tax", Media Release, July 2, 2010, available at www.minerals.org.au/_data/assets/pdf_file/MCA_News/Press\%20Releas e_2\%20July\%2010\%20_2_pdf [Accessed August 1, 2010]. discussion of mineral tax policy reform [38].

Tax reform in Australia could benefit from strategic communication, particularly given the current political climate. The current Australian Government holds minority government with a very thin balance of power, and the opposition has continued to oppose any increase of the tax paid by mining companies [39]. If all goes to plan, the Australian government will have draft legislation on the table soon, but the October 2011 Tax Summit means that the future of mining tax reform in Australia remains uncertain [40].

While Australia's favourable economic outlook presents an ideal opportunity for tax reform, the mining tax experience is a timely reminder that exhaustive consultation with key stakeholders must be undertaken, and the costs and benefits of various reform options must be painstakingly prepared, carefully assessed, and clearly presented to the public. Australia's current political environment presents policymakers with many new challenges. With neither major party able to win an absolute majority, and combined with the increased political power of the Greens and Independents in the House of Representatives - as well as the imminent takeover of the balance of power by the Greens in the Senate in July 2011 - means that achieving tax reform will likely require negotiation and compromise. Expectations of the Summit producing genuine outcomes will flatline unless a tax reform agenda and narrative are firmly established and the community is successfully engaged. The Ralph Review of Business Taxation in 1999, for example, is considered a successful exercise in tax reform, because the Government had, in advance of the consultations, laid down broad policies that it wanted to pursue [41].

Although the Mineral Resource Rent Tax represents a significant compromise between the three largest mining companies and the new Australian Prime Minister, the mining states of Queensland and Western Australia, the Federal Opposition Party, the smaller mining companies and economists, have all maintained their objections to the modified MRRT. Not only has the issue of whether or not to credit royalties paid by the mining companies to the State Governments been particularly contentious, but smaller mining companies argue the MRRT was undemocratic because they were not consulted in its development [42][45]. For example, Fortescue Metals Group chief executive Andrew Forrest argues:

"It [the MRRT] was a tax designed by BHP... It's a precedent that should not be supported. Policy should be broad ranging, it should be fair and it should be based on the constitution of being equal among states and equal among companies" [46].

It is because of these continued objections that the Australian Government has announced that it will hold consultations and negotiate with all affected stakeholders on an ongoing basis, including establishing a Policy Transition Working Group, and holding the October 2011 Tax Summit.

The Australian Government's original proposal for the taxation of mineral rents on 2 May 2010 attracted significant discontent from voters and powerful stakeholders, particularly affected mining companies. This was due in large part to the Government's perceived failure 
to initially negotiate the details of the tax with mining companies [47]. Although a significant compromise was negotiated with the three largest mining companies by the new Prime Minister, the mining states of Queensland and Western Australia, the Federal Opposition Party, the smaller mining companies, and economists, have all maintained their objections to the modified MRRT [48]. Not only has the issue of whether or not to credit royalties paid by the mining companies to the State Governments been particularly contentious, but smaller mining companies argue the MRRT was undemocratic because they were not consulted in its development. For example, Fortescue Metals Group chief executive Andrew Forrest argues:

"It [the MRRT] was a tax designed by BHP... It's a precedent that should not be supported. Policy should be broad ranging, it should be fair and it should be based on the constitution of being equal among states and equal among companies" [49].

It is because of these continued objections that the Australian Government has announced that it will hold consultations and negotiate with all affected stakeholders on an ongoing basis. It is to this end that the Australian Government established a Policy Transition Group (PTG) to undertake wide ranging consultation with industry. The PTG provided two reports to the Government on 21 December 2010, and the Australian Government accepted all 94 of the recommendations made by the PTG. These recommendations will form the basis of the design of Australia's new resource taxation arrangements, as reflected in draft legislation soon to be released for consultation [50].

The Government also established the Resource Tax Implementation Group to support the legislative drafting stage, reflecting the Government's recognition of the importance of continued industry engagement. ${ }^{2}$ This implementation group will be comprised of the Commonwealth Treasury, the Department of Resources, Energy and Tourism, the Australian Taxation Office, and a number of representatives from the resources industry and associations and taxation legal and accounting bodies [51]. It is evident from this that the Australian Government has recognised the importance of stakeholder communication in achieving successful tax reform. If all goes to plan, the Australian government will have the mining tax legislation in parliament by the end of 2011 [52].

Australia's current political environment presents policymakers with many new challenges. Achieving tax reform will likely require ongoing negotiation and compromise [53]. Expectations of the October 2011 Tax Summit producing genuine outcomes will not be fulfilled unless a tax reform agenda and narrative are firmly established and the community is successfully engaged.

Accordingly, the Australian Government should take the October 2011 Tax Summit as an opportunity to begin its round table engagement with key stakeholders. This can be done by starting with small groups to collect information on the need for reform; conducting good analyses and performing selective consultation in the solution design

\footnotetext{
${ }^{2}$ Commonwealth Government "Resource Tax Implementation Group" Department of Treasury, March 24, 2011, available at http://www.futuretax.gov.au/pages/ResourceTaxImplGroup.aspx [Accessed April 5, 2011].
}

phase; following up by broader consultations as information, arguments, and clear solutions become ready for presentation to broader audiences; preparing political processes to adopt reforms; splitting opponents by appealing to subgroups; and bringing in selectively financed incentives. Australia's failed attempt to introduce a mineral resource rent tax is a reminder that exhaustive consultation with key stakeholders must be undertaken, and the costs and benefits of various reform options must be painstakingly prepared, carefully assessed, and clearly presented to the public through strategic communication in order to develop coalitions of support for the proposed reforms [54].

\section{CONCLUSION}

The Australian Government's failure to communicate and negotiate with stakeholders caused its originally proposed Resource Super Profits Tax to fail. A better approach would have been to use strategic communication to build coalitions of key stakeholders to support the reform and drive it through. As such, some key lessons can be learned for tax reform going forward. In particular, the policy development process can be made inclusive through holding stakeholder workshops and maintaining ongoing dialogue between the Government and the private sector. The Government should continually inform players at all levels and ensure that the reform is kept on the radar of key stakeholders.

It is important to lay the groundwork to sustain longterm reform through local buy-in and deep institutional change, rather than rapid reform. This can be achieved through partnering with experienced local organisations to leverage existing relationships, as well as leveraging and co-ordinating the reform with other programs [55].

Since tax reform is always a difficult task for democratic governments, successful tax reform should be guided by a clear vision and backed up by solid analysis. Framing tax policy debates can be crucial when equity or distributional issues arise. Advancing reforms may require the acceptance of some constraints, since the more negotiable the reform details, the greater the likelihood of delay. Postimplementation evaluation and international dialogue can strengthen the case for change. The proper timing of reform is crucial, and should be linked to the business cycle. Although there are strong arguments for bundling tax reforms into comprehensive packages to address distributional issues, piecemeal reforms may be more politically acceptable. Transitional arrangement and grandfathering arrangements may offset the impact of the reform for stakeholders that are the most affected. Planning and institutionalising will increase support, and coordination of reform across levels of government is important, since the different levels need to act coherently. Successful tax reform requires strong leadership, often a political champion. Finally, for any reform, transparency and media support are crucial. In the absence of sufficient political support, politicians may want to adjust the original tax reform proposals in such a way that political support increases [56].

Tax reform is always a difficult task. It is more difficult in democracies, as various stakeholders exercise their power through a diverse range of methods of engagement. 
Mining tax reform is no exception. This is particularly so for resource rich countries, where mining companies are powerful stakeholders because they generate vast profits, some of which are retained by the government in the form of tax revenue. Like many other nations around the world, resource rich nations such as Australia are facing significant pressure for fiscal consolidation, and are accordingly looking for ways to collect more revenue for present and future generations. However, as demonstrated by the Australian experience, mining companies will always resist any reduction of their revenue due to increased taxes. Accordingly, policy makers are facing conflicting objectives. In order to achieve a win-win solution, policy makers need to adopt strategic communication tools that will not only ensure a smooth transition from one tax policy to the other, but will also assist in maintaining harmonious relationships between all stakeholders affected by the proposed tax reform proposals.

Hence, the Australian Government should use the lead up to the October 2011 Tax Summit to communicate strategically with key stakeholders, particularly mining companies, in order to develop the coalitions of support that are necessary to introduce a reform as significant as the mineral resource rent tax.

\section{REFERENCES}

[1] International Monetary Fund, "From Stimulus to Consolidation: Revenue and Expenditure Policies in Advanced and Emerging Economies", Fiscal Affairs Department, 2010.

[2] International Monetary Fund, "From Stimulus to Consolidation: Revenue and Expenditure Policies in Advanced and Emerging Economies", Fiscal Affairs Department, 2010.

[3] Commonwealth Government, "Australia's future tax system: Final Report," Department of Treasury, May 2010.

[4] T. Sarker, and E Whalan, "Reform issues in mineral tax policy for economic development: the Mineral Resource Rent Tax in Australia", Bulletin for International Taxation, 65 (1): 1-25, 2010.

[5] J. Pope, "Personal income tax reform: consensus, outliers, specifics and the longer-term socio-economic context," Personal Income Tax Reform Symposium, 2007.

[6] J. Fidrmuc, and A. Noury, "Interest groups, stakeholders and the distribution of benefits and costs of reform," GDN Global Research Project Understanding Reform, 2003.

[7] A. Weiss, "Cracks in the Foundation of Stakeholder Theory," Electronic Journal of Radical Organisation Theory, 1(1):1-13, 1995.

[8] B. Nerre, "Tax culture: a basic concept for tax politics", Economic Analysis and Policy, 38(1), 2008.

[9] OECD, "Making reform happen: lessons from OECD Countries", 2010.

[10] T. Sarker, and E Whalan, "Reform issues in mineral tax policy for economic development: the Mineral Resource Rent Tax in Australia", Bulletin for International Taxation, 65 (1): 1-25, 2010.

[11] R. Mitchell, B. Agle, and D. Wood, "Toward a theory of stakeholder identification and salience: defining the principle of who and what really counts," Academy of Management Review, 22: 853-886, 1997.

[12] R. Lozano, "Proposing a corporate sustainability stakeholder typology," Sustainability Research Institute, 2010.

[13] Department of Innovation, Industry, Science and Research, "Australia's Exports Fact Sheet", Commonwealth Government (2010), available www.innovation.gov.au/section/aboutdiisr/factsheets/pages/australia $\% 27$ sexportsfactsheet.aspx.

[14] G. Duggin, "Submission writing for policy and law reform," Environmental Defender's Office, New South Wales, 2010.

[15] G. Duggin, "Submission writing for policy and law reform," Environmental Defender's Office, New South Wales, 2010.

[16] World Bank, "Stakeholder management in business registration reforms: lessons from ten countries," 2009.

[17] G. Duggin, "Submission writing for policy and law reform," Environmental Defender's Office, New South Wales, 2010.

[18] World Bank, "Stakeholder management in business registration reforms: lessons from ten countries," 2009.
[19] [S. Rahman, "Using strategic communications to engage stakeholders in tax reform," Investment Climate in Practice - Business Taxation, 15: $1-8,2010$.

[20] S. Rahman, "Using strategic communications to engage stakeholders in tax reform," Investment Climate in Practice - Business Taxation, 15: 1-8, 2010.

[21] World Bank, "Stakeholder management in business registration reforms: lessons from ten countries," 2009.

[22] World Bank, "Stakeholder management in business registration reforms: lessons from ten countries," 2009.

[23] World Bank, "Stakeholder management in business registration reforms: lessons from ten countries," 2009.

[24] World Bank, "Stakeholder management in business registration reforms: lessons from ten countries," 2009.

[25] World Bank, "Stakeholder management in business registration reforms: lessons from ten countries," 2009.

[26] OECD, "Making reform happen: lessons from OECD Countries", 2010.

[27] R. Garnaut and A. Clunies-Ross, Taxation of Mineral Rents, above fn. 12.

[28] International Monetary Fund, From Stimulus to Consolidation: Revenue and Expenditure Policies in Advanced and Emerging Economies, (2010) Fiscal Affairs Department, available at www.imf.org/external/np/pp/eng/2010/043010a.pdf [Accessed April $12,2011]$

[29] Commonwealth Government, "2010-2011 Budget", (2010), available at www.budget.gov.au. [Accessed May 9, 2010].

[30] Commonwealth Government, Australia's future tax system: Final Report Part 1 (2010) Department of Treasury, available at www.futuretax.gov.au (Henry Tax Review) [Accessed May 9, 2010].

[31] N. Charnock, "Redesign of Super Tax" Safehaven, June 16, 2010, available at http://www.safehaven.com/article/17168/redesign-ofsuper-tax [Accessed 19 March, 2011].

[32] D. Fickling and R. Thurlow. "Kevin Rudd's tax plan hammers mining shares, poses risk to mergers". The Australian, 3 May, 2010, available at http://www.theaustralian.com.au/business/in-depth/kevinrudds-tax-plan-hammers-mining-shares-poses-risk-to-mergers/storyfn5eo6td-1225861636793

[33] Queensland Resources Council, Personal Communication, Seminar on the Resources Super Profits Tax, June 15, 2010; Minerals Council of Australia "Minerals, Resources and the prosperity of all Australians", (2010) Policy Brief , available at www.minerals.org.au/_data/assets/pdf_file/MCA_News/MCA_Futu re Tax_System.pdf [Accessed August 1,2010$]$;

[34] Minerals Council of Australia "Minerals Resource Rent Tax", Media Release, July 2, 2010, available at www.minerals.org.au/_data/assets/pdf_file/MCA_News/Press\%20R elease_2\%20July\%2010\%20_2_pdf [Accessed August 1, 2010].

[35] J. Pope "Personal income tax reform: consensus, outliers, specifics and the longer-term socio-economic context," paper presented to the Personal Income Tax Reform Symposium, University of New South Wales, Sydney, April 2-3 2007, available at www.atax.unsw.edu.au/research/pitr-symposium.../papers/Paper_14Pope.pdf [Accessed March 4, 2011].

[36] B. Nerre, "Tax culture: a basic concept for tax politics", Economic Analysis and Policy, Vol. 38, No. 1 (2008), pp. 153;

[37] Y. Pesquex, "Network, stakeholder theory and deliberative democracy", Journal of Innovation Economics, Vol. 2 (2009), pp. 6378.

[38] Verrender, Ian "An opportunity missed on mining super tax" Sydney Morning Herald, 15 February 2011, available at www.smh.com.au

[39] N. Horne, "Hung parliaments and minority governments," Australian Policy Online, 2011.

[40] S. Ryan, "GST not on the tax summit agenda, says Julia Gillard," The Australian, 11 January 2011.

[41] Deloittes "The road to tax reform in 2011: An economic perspective", 2010.

[42] M. Chambers, "Proposed mining tax worse than royalties, say economists" The Australian, March 31, 2011, available at http://www.theaustralian.com.au/business/proposed-mining-taxworse-than-royalties-say-economists/story-e6frg8zx-1226030987988 [Accessed April 4, 2011]

[43] D. Fickling and R. Thurlow. "Kevin Rudd's tax plan hammers mining shares, poses risk to mergers". The Australian, 3 May, 2010, available at http://www.theaustralian.com.au/business/in-depth/kevinrudds-tax-plan-hammers-mining-shares-poses-risk-to-mergers/storyfn5eo6td-1225861636793

[44] E. Rodgers, "Rudd left out of Gillard's reshuffle", $A B C$ News, June 28, 2010 , available 
www.abc.net.au/news/stories/2010/06/28/2938876.htm [Accessed September 5, 2010]

[45] C. Zappone, "Ceasefire between miners and government", Sydney Morning Herald, June 24, 2010, available at www.smh.com.au/business/ceasefire-between-miners-andgovernment-20100624-z14a.html [Accessed August 2, 2010].

[46] R. Lawson "Government fails to win miners over with MRRT" PerthNow, March 24, 2011, available at http://www.perthnow.com.au/business/government-fails-to-winminers-over-with-mrrt/story-e6frg2r3-1226027577510 [Accessed April 11, 2011].

[47] Minerals Council of Australia, "Minerals resources, tax, and the prosperity of all Australians", Policy brief (June 2010), available at: www.minerals.org.au/_data/assets/pdf_file/MCA_News/MCA_Futu re_Tax_System.pdf.

[48] M. Chambers, "Proposed mining tax worse than royalties, say economists" The Australian, March 31, 2011, available at http://www.theaustralian.com.au/business/proposed-mining-taxworse-than-royalties-say-economists/story-e6frg8zx-1226030987988 [Accessed April 4, 2011].

[49] R. Lawson "Government fails to win miners over with MRRT" PerthNow, March 24, 2011, available at http://www.perthnow.com.au/business/government-fails-to-winminers-over-with-mrrt/story-e6frg2r3-1226027577510 [Accessed April 11, 2011].

[50] Commonwealth Government "Resource Tax Implementation Group" Department of Treasury, March 24, 2011, available at http://www.futuretax.gov.au/pages/ResourceTaxImplGroup.aspx [Accessed April 5, 2011].

[51] Commonwealth Government "Government Accepts Resource Tax Recommendations" Media Release, March 24, 2011, available at
http://www.futuretax.gov.au/pages/MediaCentre.aspx\#24032011 [Accessed April 2, 2011].

[52] "Mining tax laws due by end of 2011" The Northern Star, March 24, 2011, http://www.northernstar.com.au/story/2011/03/24/mining-taxlaws-due-by-end-of-2011/ [Accessed April 2, 2011].

[53] Deloittes "The road to tax reform in 2011: An economic perspective", 2010.

[54] World Bank, "Stakeholder management in business registration reforms: lessons from ten countries," 2009.

[55] S. Rahman, "Using strategic communications to engage stakeholders in tax reform," Investment Climate in Practice - Business Taxation, 15: $1-8,2010$

[56] OECD, "Making reform happen: lessons from OECD Countries", 2010 .

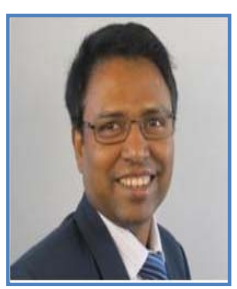

Tapan Sarker $(\mathrm{PhD}$, Australian National University) is a Lecturer and Researcher with Griffith Business School, Griffith University, Australia. He also works as a Tax Policy Consultant with the World Bank, Asian Development Bank and IMF. Dr Sarker is currently listed as an expert in Tax Policy with the Fiscal Affairs Department of International Monetary Fund. His research has been published in pretigious tax journals, including Bulletin for International Taxation, Asia Pacific Tax Bulletin etc. Dr Sarker was a keynote speaker at the 2011 International Conference on Financial Management and Economics - ICFME 2011 held in Hong Kong, July 2-3, 2011. Dr Sarker can be contacted at <tapan.sarker@griffith.edu.au> 